\title{
Composition of the TTL over Darwin: local mixing or long-range transport?
}

\author{
W. J. Heyes ${ }^{1}$, G. Vaughan ${ }^{1}$, G. Allen ${ }^{1}$, A. Volz-Thomas ${ }^{2}$, H.-W. Pätz ${ }^{2}$, and R. Busen ${ }^{3}$ \\ ${ }^{1}$ SEAES, University of Manchester, Manchester, UK \\ ${ }^{2}$ ICG-2, Forschungszentrum Jülich, Jülich, Germany \\ ${ }^{3}$ Institute of Atmospheric Physics, DLR Oberpfaffenhofen, Oberpfaffenhofen, Germany
}

Received: 26 February 2009 - Published in Atmos. Chem. Phys. Discuss.: 20 March 2009

Revised: 26 August 2009 - Accepted: 25 September 2009 - Published: 19 October 2009

\begin{abstract}
We present ozone and carbon monoxide measurements taken in Darwin, Australia, during the wet season of 2005/2006, to examine whether the composition of the Tropical Tropopause Layer (TTL) reflects that of the local boundary layer or is influenced more by advection from distant sources. We find that the latter predominates in the upper TTL, and is also the major influence in the lower TTL, except during an active monsoon phase. The day-to-day variability of ozone in the TTL is far greater than that in the lower troposphere, and correlates closely with air mass origin deduced from trajectory calculations based on standard ECMWF wind analyses. Although clear evidence of recent local uplift was found in carbon monoxide tracer measurements recorded inside convective anvils, no such signal was found out-of-cloud in the background TTL, where the measured variability correlated well with air mass origin deduced from back-trajectories. This study suggests that the composition of the TTL is ultimately determined by vertical mixing in certain "hot spot" regions of the tropics, with advection from these regions dominating the composition elsewhere.
\end{abstract}

\section{Introduction}

The Tropical Tropopause Layer (TTL) is a transition region between the convectively-driven tropical troposphere and the radiatively-controlled stratosphere, where the chemical

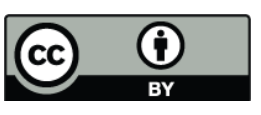

Correspondence to: W. J. Heyes

(william.heyes@postgrad.

manchester.ac.uk) and dynamical properties of each gradually interchange (Fueglistaler et al., 2009). Although several differing definitions have been used for the TTL (Highwood and Hoskins, 1998; Gettelman and Forster, 2002; Fueglistaler et al., 2009), in general it can be considered to extend from the region of main convective outflow ( $\sim 12-14 \mathrm{~km}$; Folkins et al., 1999), to the position of minimum temperature or "cold point" tropopause ( $\sim 17-19 \mathrm{~km}$; Thuburn and Craig, 2002).

Acting to couple the tropospheric Hadley circulation with the wider stratospheric Brewer-Dobson circulation, the TTL acts as a major source region for air entering the stratosphere, thus influencing the concentration of trace constituents important for the chemical balance of the ozone layer as well as climate (Holton et al., 1995). These constituents include water vapour, $\mathrm{N}_{2} \mathrm{O}$ and halogen-containing species, which are important source gases for radicals involved in the production and destruction of stratospheric ozone. Vertical transport within the lower region of the TTL is thought to be dominated by convection; however the frequency of convective penetration drops rapidly with height, with slower, radiatively-driven, ascent dominating within the upper TTL (Gettelman et al., 2004). The partitioning between these two vertical transport regimes depends on height, location and season, with their relative contributions changing vertically over just a few kilometres. Moreover, quasi-horizontal transport, for both redistribution of components within the TTL itself and for exchange processes with the extratropical stratosphere, also has a large influence on TTL composition (Holton and Gettelman, 2001; Konopka et al., 2007).

A recent review of our knowledge of the TTL by Fueglistaler et al. (2009) points to the continuing uncertainty

Published by Copernicus Publications on behalf of the European Geosciences Union. 
surrounding the role of deep convection in transporting chemical species into the TTL. There is no doubt that the process does happen: aircraft measurements in the anvils of deep convective outflow have frequently found elevated carbon monoxide (CO), hydrocarbons and other gases of lowlevel origin (e.g. Dickerson et al., 1987), consistent with cloud-scale modelling results (e.g. Pickering et al. 1992). The question we investigate in this paper is whether such uplift has a significant impact on the background (out-of-cloud) TTL in the vicinity of convection, or whether the composition of the TTL is better characterised by long-range transport from more distributed and distant source regions. This question is relevant to accurate global modelling of the TTL; if local uplift determines the composition then modelling has the formidable task of representing cloud-scale transport correctly, whereas if local influences are minor, large-scale resolvable flow will dominate. The relative proportion is expected to depend upon altitude (with local convection more likely to dominate the lower TTL) and geographical position (with "hot spots" like the Tropical Warm Pool, with its widespread deep convection, more likely to influence the local TTL).

The measurements we use in this study were obtained in Darwin, Australia during the 2005-2006 wet season (November-February). As we describe below, these measurements cover a range of meteorological and low-level chemical regimes, ranging from isolated land-based storms in the presence of widespread biomass burning, to the monsoon-trough, characterised by widespread oceanic convection.

\section{The ACTIVE campaign}

The measurements used here were obtained during the Aerosol and Chemical Transport in tropIcal conVEction (ACTIVE) aircraft field campaign, summarised by Vaughan et al. (2008) and May et al. (2008). The campaign was conducted from Darwin, Northern Australia $\left(12.47^{\circ} \mathrm{S}\right.$, $130.85^{\circ} \mathrm{E}$ ), in two periods: 10 November $2005-12$ December 2005, and 20 January 2006-17 February 2006. It was based on measurements using ozonesondes and two research aircraft: a Dornier-228 carrying a suite of instruments capable of measuring chemical and aerosol constituents in the boundary layer and lower free troposphere (up to an altitude $\sim 4 \mathrm{~km}$ ); and the Airborne Research Australia (ARA) Grob G520T Egrett, operated primarily in the region of main convective outflow (up to $\sim 15 \mathrm{~km}$ ), and equipped with instrumentation for cirrus microphysical analysis, in addition to chemical and aerosol measurements. Details of the aircraft instrumentation may be found in Vaughan et al. (2008). Of particular importance to this paper was a $\mathrm{CO}$ analyser onboard the Egrett aircraft, and a total of thirty-five ozonesondes launched from the Australian Bureau of Meteorology site located adjacent to Darwin Airport $\left(12.42^{\circ} \mathrm{S}, 130.89^{\circ} \mathrm{E}\right)$.
Full tropospheric ozone profiles were obtained from twentynine of these soundings, in addition to simultaneous atmospheric pressure, temperature, relative humidity and horizontal wind measurements.

Darwin is situated close to the so-called "maritime continent" (incorporating Indonesia and the surrounding region) and the Tropical Warm Pool, where mesoscale convective systems are among the deepest on the planet (Crook, 2001). During the wet season (roughly October-April), Darwin typically experiences two broad meteorological regimes. The pre-monsoon and monsoon break regimes are characterised by easterly winds below $300 \mathrm{hPa}$ and very deep landbased convection, usually initiated by sea-breezes and therefore most prevalent in the afternoon and evening. In contrast, the monsoon regime, typically lasting 1-2 weeks at a time when the active phase of the Madden-Julian oscillation (MJO) passes over Darwin, is characterised by widespread oceanic convection and westerly winds below $300 \mathrm{hPa}$. Monsoon convection is generally regarded to be shallower than the land-based convection of the easterly regime, but the ACTIVE observations revealed a wide range of cloud top heights during the monsoon with some cloud-tops reaching the tropopause (May et al., 2008). Of particular interest to the work reported here is the so-called Hector thunderstorm which develops almost daily in the pre-monsoon and monsoon break periods over the Tiwi Islands, $100 \mathrm{~km}$ north of Darwin. The reliable occurrence of this very deep storm, and its isolation from mainland convection, makes it the ideal subject for case studies, and indeed the Tiwi Islands have been described as a "natural laboratory" for studies of deep convection (Wilson et al., 1999).

The Darwin region is remote from major sources of industrial pollution, although, as we shall describe in the following section, biomass burning is prevalent during the premonsoon season. In the absence of pollution, ozone destruction dominates the lower troposphere and boundary layer, where high levels of solar radiation coincide with a high moisture content. This facilitates the following reactions (Kley et al., 1996):

$\mathrm{O}_{3}+h v \rightarrow \mathrm{O}\left({ }^{1} D\right)+\mathrm{O}_{2}(\lambda<320 \mathrm{~nm})$

$\mathrm{O}\left({ }^{1} D\right)+\mathrm{H}_{2} \mathrm{O} \rightarrow 2 \mathrm{OH}$

with $\mathrm{OH}$ removed by a variety of species (e.g. methane, $\mathrm{CO}$ ). With a photochemical lifetime of only a few days, the concentration of ozone in the tropical marine boundary layer tends to be low $-20 \mathrm{ppbv}$ or less. Indeed, in very remote tropical marine environments near-zero surface ozone concentrations can occur (e.g. Kley et al., 1996). Above the boundary layer, the water vapour mixing ratio decreases sharply, thus the photochemical lifetime of ozone increases - reaching the order of months in the upper troposphere (Thompson et al., 1997). As such, the ozone concentration in the upper troposphere tends to be governed by transport and chemical production, making it useful as a tracer of vertical transport from 
the boundary layer to the TTL. Similarly carbon monoxide is an excellent tracer of tropospheric dynamics by virtue of its long lifetime throughout the entire troposphere (of the order of 1 month) and is especially useful as a convective tracer in areas where there is a strong gradient in concentration between the surface and the outflow region. Correlations (and anti-correlations) between $\mathrm{CO}$ and ozone can also give useful information on the photochemical age and nature of mutual surface sources, e.g. from biomass burning plumes. Hence the lifetime of both $\mathrm{CO}$ and ozone in the upper troposphere justifies the use of back-trajectory calculations in the upper troposphere in this work (see Sect. 4).

Throughout this manuscript we make use of several terms which we here define. Of central importance to this work is the idea of "local mixing" verses "long-range transport", and so is necessary to define the spatial scales referred to by this. We use the term "local" to indicate coupling of the boundary layer and TTL through individual convective systems and so indicate spatial scales of $\sim 100 \mathrm{~km}$, whereas "longrange" refers to spatial scales of $\sim 1000 \mathrm{~km}$ representative of the wider convective region of the tropical warm pool. We use the term "background TTL" to describe measurements made outside convective outflow regions; as described later (see Sect. 4) clear evidence of local uplift was observed from Egrett measurements inside convective outflow but was seldom observed in clear air.

\subsection{Ozonesonde instrumentation}

Electrochemical concentration cell (ECC) ozonesondes launched through the course of ACTIVE were coupled with Vaisala RS92-KE radiosondes, providing vertical pressure, temperature and humidity data in addition to horizontal winds. Following the recommendation of Reid et al. (1996), a constant background current correction was applied to ozonesonde measurements throughout the troposphere, in preference to the standard pressure-varying correction. Ozonesonde profiles treated in this way were consistent with those from the Geophysica aircraft on corresponding flight days, within $\sim 5 \mathrm{ppbv}$ (profiles not shown). Unfortunately, the ozone sensor on the Egrett aircraft did not give reliable data for most of the flights and is only used here in support of other observations (Sect. 4.4).

\subsection{Carbon monoxide instrumentation}

Carbon monoxide data was collected onboard the Egrett aircraft with a resonance fluorescence instrument (Volz and Kley, 1985; Gerbig et al., 1999). The instrument deployed in ACTIVE aboard the Egrett was custom-built around the fluorescence block of an AERO-Laser, Model $502 \mathrm{CO}$ analyser. The instrument was regularly calibrated, both on the ground and during flight. Data were collected at a frequency of $1 \mathrm{~Hz}$ with a precision of $\pm 2 \mathrm{ppbv}$ and an accuracy of $\pm 3 \mathrm{ppbv}$ ( $5 \%$ at mixing ratios $>60 \mathrm{ppb}$ ).

\section{Meteorological overview}

With the exception of a brief period around 21-26 November 2005, when a westerly "mini-monsoon" affected Darwin (Allen et al., 2009), the first period of the ACTIVE campaign (November-December 2005) experienced easterly winds up to mid-levels, with low-level sea-breeze convergence initiating localised convection as previously noted. Aerosol measurements recorded by the Dornier aircraft showed a strong contrast across this period. From 10-27 November 2005 elevated mass loadings of aerosol were observed to be well correlated with enhancements in $\mathrm{CO}$ and black carbon (Allen et al., 2008a, b), consistent with the prevalence of nearby biomass burning sources; hence we refer to this period as the "Biomass Burning" phase of the ACTIVE campaign. As the season progressed, the burning sources abated and aerosol concentrations decreased: images from the Moderate-resolution Imaging Spectroradiometer (MODIS) (Fig. 1) show a marked decrease in the number of fires both close to Darwin and over Indonesia between October and December. We refer to the period 30 November 2005-10 December 2005 as the "Pre-monsoon" phase of ACTIVE. It should be emphasized that the meteorological regime was similar in November and December, and it is only the local biomass burning which changed. The fires shown on the east coast of Australia in both MODIS plots (Fig. 1) helped maintain the aerosol population around Darwin throughout both phases, but the concentration was reduced in the "pre-monsoon" phase due to the relative absence of local sources.

The second period of the ACTIVE campaign (JanuaryFebruary 2006) experienced both the meteorological regimes described earlier. A monsoon trough formed to the south of Darwin on 12 January 2006 with associated westerly winds up to $300 \mathrm{hPa}$ at Darwin. The monsoon phase lasted until the beginning of February, with an active period (widespread deep convection over ocean and land) up to 24 January 2006 followed by an inactive period during which deep convection ceased in the Darwin area (May et al., 2008). A reversal to easterly winds occurred after 3 February 2006, as the active phase of the MJO moved to the Pacific. During this "Monsoon-Break" period (6-15 February 2006) easterly winds up to mid-levels returned, similar to pre-monsoon conditions, resulting again in the formation of isolated deep convective systems.

\section{Observations and results}

\subsection{Mean profiles of ozone and $\mathrm{CO}$}

Figure 2 illustrates the evolution of average ozone and carbon monoxide profiles during the four phases of the ACTIVE campaign. Other than in the monsoon phase, the ozone profiles display the "S" shape characteristic of the tropical 


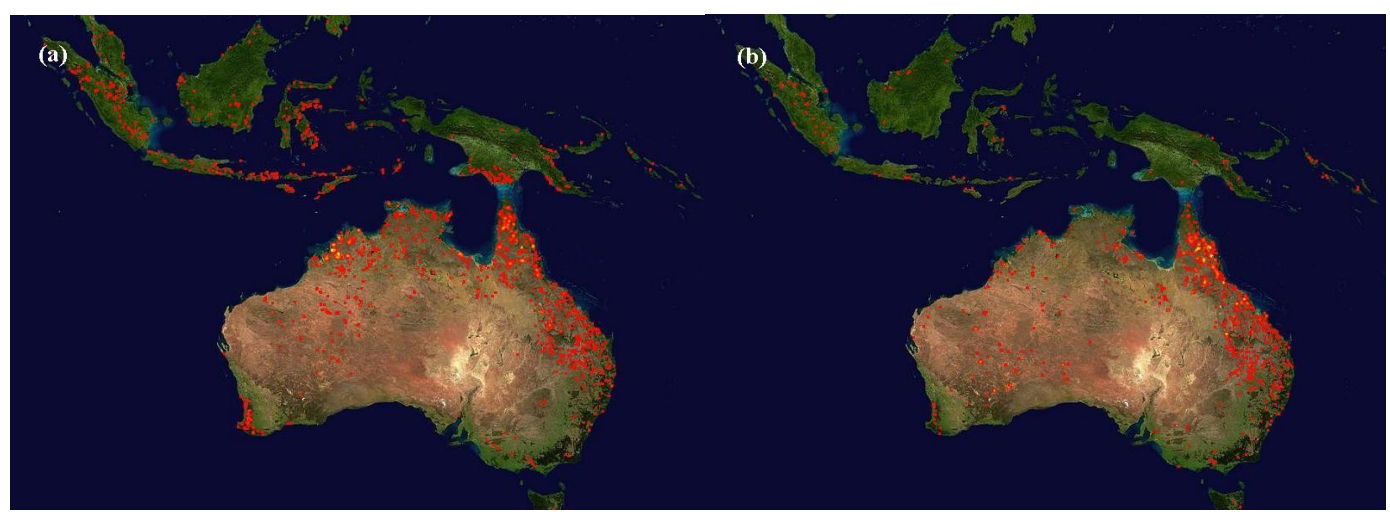

Fig. 1. MODIS fire plots displaying active burning regions between (a) 7 November 2005 to 16 November 2005 and (b) 7 December 2005 to 16 December 2005, highlighting the contrast in local biomass burning sources in the Darwin area between the Biomass Burning and Pre-monsoon periods.
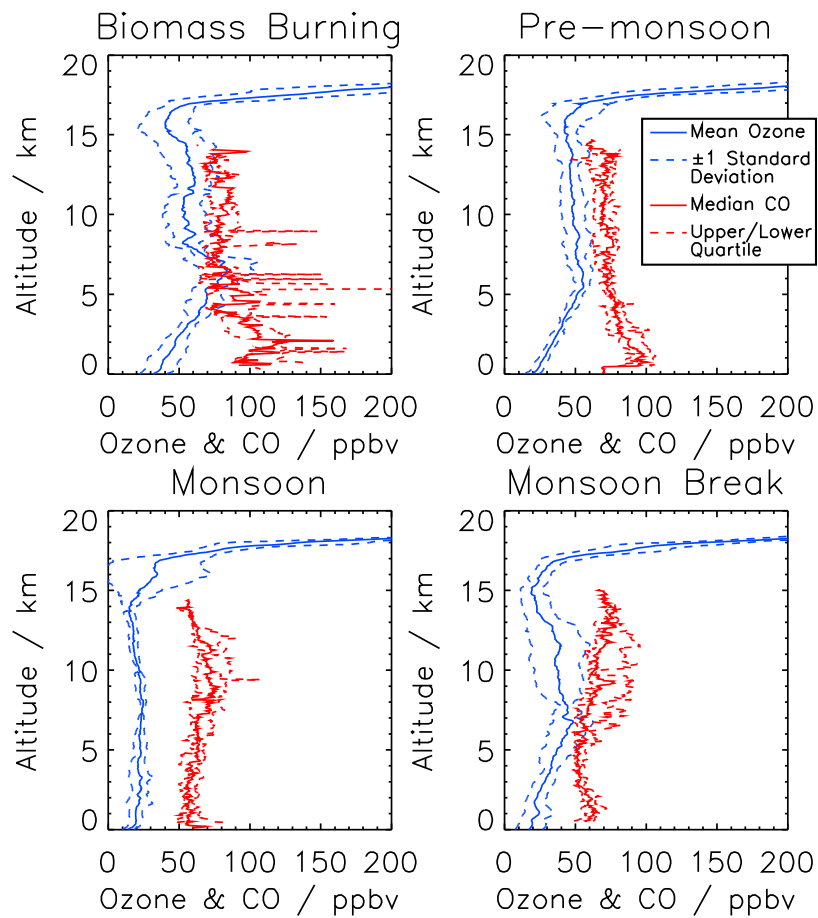

Fig. 2. Mean ozone and median carbon monoxide profiles, from ozonesonde and Egrett aircraft measurements respectively, recorded during the biomass burning, pre-monsoon, monsoon and monsoon break periods. Variability is expressed by 1 standard deviation of the mean for ozone measurements, and the upper and lower quartiles for carbon monoxide measurements.

warm pool (Thompson et al., 2003), with low values at the surface and in the TTL separated by higher values in the mid-troposphere. In contrast, the active monsoon profiles essentially show constant ozone concentrations up to the base of the TTL. In the boundary layer, concentrations were unchanging at around $20 \mathrm{ppbv}$ during the three later phases, indicating a regime of photochemical destruction. Abundant photochemical ozone precursors from the fires resulted in the higher concentration ( $40 \mathrm{ppbv}$ ) observed during the biomass burning phase. Of note in this phase was the incursion of tropopause folds over Darwin during the "mini-monsoon" period (see Allen et al., 2009, for further details), resulting in a high average ozone concentration seen in the midtroposphere in Fig. 2. However, in all four meteorological phases, ozone in the TTL was highly variable - particularly in the monsoon phase when a range of 3-80 ppbv contrasted markedly with the near-constant ozone concentration in the atmosphere beneath.

The average $\mathrm{CO}$ profiles, while not extending into the upper TTL, tell a similar story. High CO concentrations at low level in the first two phases are consistent with biomass burning (the Egrett flights in November missed the period of tropopause fold influence), with a strong decrease in concentration with altitude. In contrast, during the monsoon break phase, $\mathrm{CO}$ increased with altitude as very clean marine air was advected over Darwin at low levels.

\subsection{Evidence for vertical coupling}

We now consider to what extent the composition of the TTL may be taken to reflect that of the local boundary layer. One of the most striking features of the ozonesonde profiles (in Fig. 2) is the extent to which both very high and very low episodes of ozone were measured in the TTL when lowlevel concentrations were almost unchanging. Figure 3 illustrates this for isolated deep-convective conditions, experienced within the pre-monsoon and monsoon break periods. Boundary layer ozone concentrations on 10 November 2005 (40-50 ppbv; Fig. 3a) were significantly greater than in the TTL, where concentrations reached as low as 15 ppbv. Conversely on 22 November 2005 (Fig. 3b) boundary layer ozone concentrations around $40 \mathrm{ppbv}$ were significantly lower than the TTL, which varied from $65-85$ ppbv. 
This contrast was not confined to periods of isolated deep convection. Even during the monsoon phase when convective activity covered the wider Darwin region, large variations in ozone were observed in the TTL. Figure $3 \mathrm{c}$, from 20 January 2006, illustrates an instance of elevated ozone in the upper TTL, reaching $\sim 80 \mathrm{ppbv}$, compared with 20 $35 \mathrm{ppbv}$ below $14 \mathrm{~km}$. This is in contrast to the profile from 22 January 2006 (Fig. 3d) where similar concentrations (15$30 \mathrm{ppbv}$ ) were observed up to $13 \mathrm{~km}$, but very low ozone $(<5 \mathrm{ppbv})$ was observed at $16 \mathrm{~km}$.

Such profiles suggest that long-range transport plays an important role in determining the composition of the TTL in the Darwin area, whilst localised convection does not appear to significantly perturb the background TTL. To examine this hypothesis further we now present back-trajectories using standard meteorological analyses, to determine whether the ozone variability observed in the TTL correlates with air mass origin.

Although the calculations use only the (large-scale) analysed winds, many of these trajectories ascend rapidly from low levels over the course of a couple of days. These rapid uplifts occur in regions of widespread deep convection, where the convective parameterisation in the European Centre for Medium-range Weather Forecasting (ECMWF) Integrated Forecasting System model (further details below) generates large-scale uplift of mass and resulting upper-level divergence. The analysed vertical velocity reflects this forcing, allowing the model trajectories to represent, in a qualitative fashion, uplift from low-level by widespread deep convection.

\subsection{Trajectory analysis applied to ozonesonde profiles}

For each ozone profile the ozone concentration was determined at $5 \mathrm{hPa}$ intervals from 200 to $100 \mathrm{hPa}(\sim 12.5-$ $16.5 \mathrm{~km}$, every $0.2 \mathrm{~km})$. Ten-day back trajectories were then calculated from a cluster of points around Darwin $\left(0.5^{\circ} \mathrm{spac}-\right.$ ing) at each level. This meant a total of 21 clustered trajectories were performed through the TTL for each profile. With 29 ozonesonde profiles collected, a total of 609 backtrajectories in the TTL were performed (or 3045 including the cluster trajectories). Calculations used the ECMWF operational analyses from the Integrated Forecasting System (IFS Cycle $29 \mathrm{r} 2$ ) on a $2.5^{\circ} \times 2.5^{\circ}$ grid on 21 pressure levels, and were performed using the trajectory server at the British Atmospheric Data Centre (BADC) using wind-fields derived from ECMWF operational data.

The consistency of these clustered trajectories was examined using the following method: each cluster was checked for significant divergence by ensuring that the "final position" of all clustered points was within $\pm 5^{\circ}$ latitude and longitude of the central trajectory horizontally, and $\pm 50 \mathrm{hPa}$ vertically for those trajectories that remained above the $500 \mathrm{hPa}$ surface, or $\pm 100 \mathrm{hPa}$ for those trajectories that descended below it. Table 1 details the numbers of trajectories rejected by

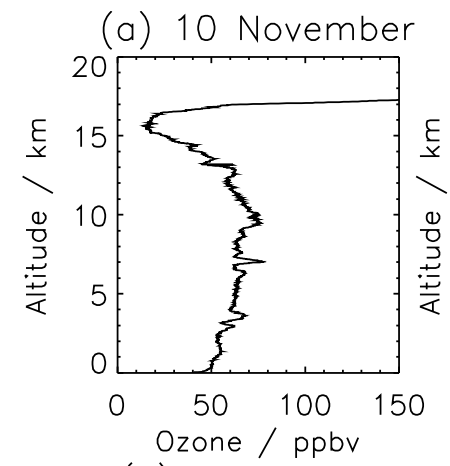

(b) 22 November
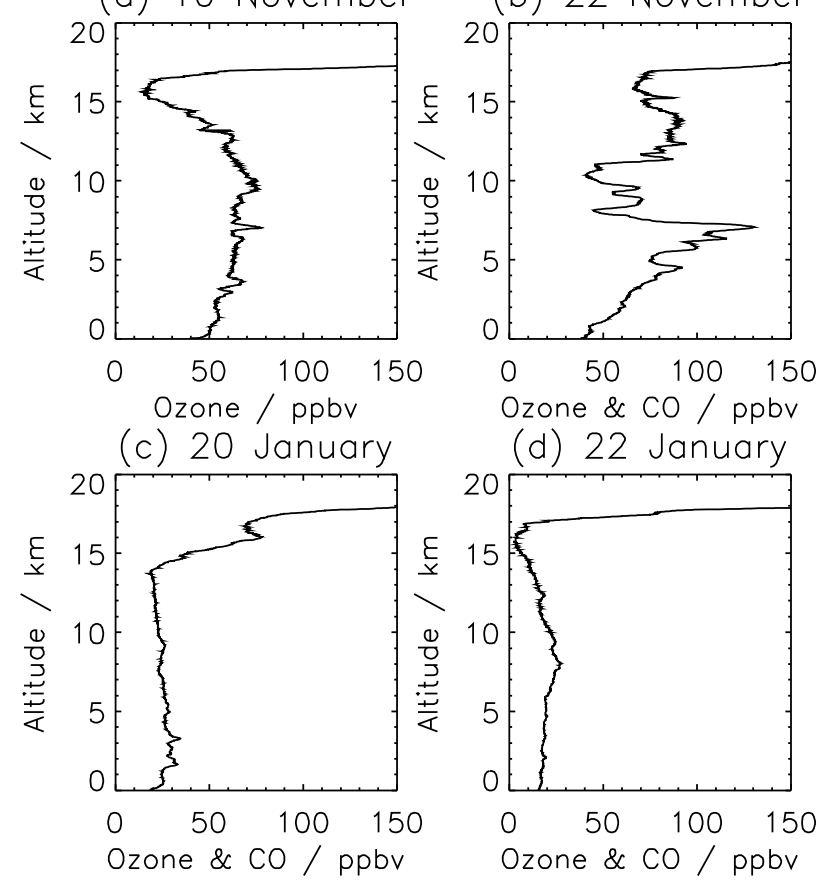

Fig. 3. Example ozonesonde profiles from the pre-monsoon period on (a) 10 November 2005 and (b) 22 November 2005; and during the monsoon period on (c) 20 January 2006 and (d) 22 January 2006.

this method, broken down by period. Overall, $21.7 \%$ of trajectories were rejected, with the greatest proportion $(32.1 \%)$ in the pre-monsoon phase. The "final position" of each trajectory cluster was defined to be the point at which the central trajectory crossed the $500 \mathrm{hPa}$ surface for trajectories uplifted from low-level, or the end-point of the ten-day trajectory for those that did not. We do not consider trajectories of greater than 10 days in length due to the cumulative uncertainty in the integration and the loss of air parcel integrity due to mixing effects.

Table 2 quantifies the proportion of trajectories that experienced significant uplift for the contrasting meteorological regimes. This was calculated by grouping the backtrajectories ending in the TTL over Darwin, into pressure bins for every $25 \mathrm{hPa}$ between 200 and $100 \mathrm{hPa}$, and calculating the percentage of trajectories that originated below the $500 \mathrm{hPa}$ isosurface. Each period shows the overall pattern of a decreasing proportion of convective ascent with altitude, i.e. air parcels which were observed in the uppermost TTL over Darwin generally experienced much less uplift (over the previous 10 days) than those air parcels in the lowermost TTL, consistent with the conclusions of Gettelmann et al. (2002). For all but the pre-monsoon phase, around $70 \%$ of trajectories (averaged across the entire $200-100 \mathrm{hPa}$ range) experienced uplift, but for the pre-monsoon phase this fraction was much lower, at $18 \%$, suggesting that very 
Table 1. The percentage of clustered back-trajectories from the ozonesonde profiles rejected due to divergence during each meteorological period, and the aggregated average of trajectories rejected.

\begin{tabular}{lcc}
\hline Phase & \multicolumn{2}{c}{ Trajectories Rejected/\% } \\
\hline & Phase Average & Aggregated Average \\
\cline { 2 - 3 } $\begin{array}{l}\text { Biomass Burning } \\
\text { (10 Nov-27 Nov 2005) }\end{array}$ & 11.9 & \\
$\begin{array}{l}\text { Pre-monsoon } \\
\text { (30 Nov-10 Dec 2005) }\end{array}$ & 32.1 & 21.7 \\
$\begin{array}{l}\text { Monsoon } \\
\text { (20 Jan-23 Jan 2006) }\end{array}$ & 17.5 \\
$\begin{array}{l}\text { Monsoon Break } \\
\text { (6 Feb-15 Feb 2006) }\end{array}$ & 12.7 \\
\hline
\end{tabular}

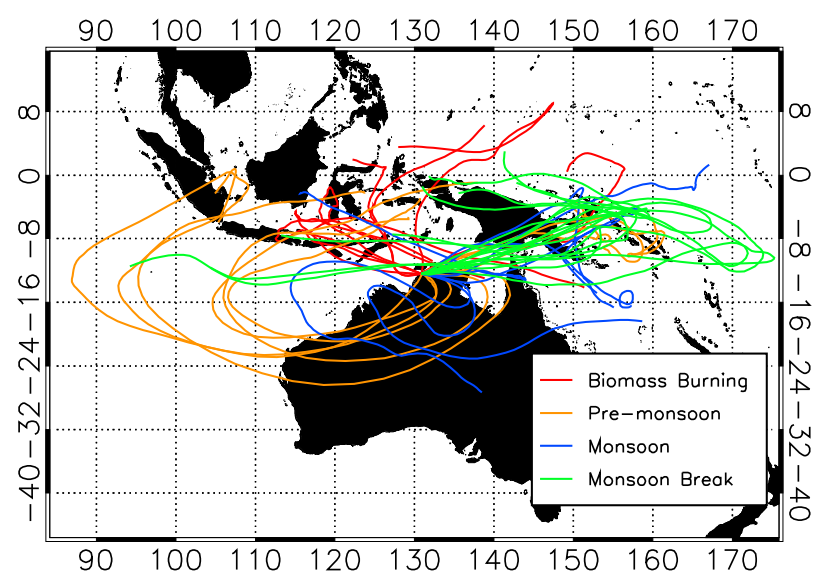

Fig. 4. Map showing the full ten-day pathway for back trajectories uplifted from below the $500 \mathrm{hPa}$ surface, used in the analysis of ozonesonde data. These have been colour-coded to meteorological period. Each displayed trajectory represents a number of calculated back-trajectory clusters aggregated together.

long-range or diffuse sources dominated the TTL composition at this time; such air parcels had not been in contact with the surface for at least 10 days. The higher proportion of rejected trajectories during the pre-monsoon phase is consistent with more of the calculations running for the full 10 days, and hence more time for clusters to diverge from the consistency constraints outlined above.

Figure 4 shows the full ten-day back-trajectory pathways for trajectories that ascended from below the $500 \mathrm{hPa}$ surface, while Fig. 5 shows the position where uplifted trajectories crossed the $500 \mathrm{hPa}$ surface marked by the associated ozonesonde concentration measurement recorded at the beginning of each trajectory. The colour represents the meteorological phase. Results are only shown when the trajectories correspond to relatively constant features in the ozonesonde profiles, to ensure that the values shown represent a significant layer of air. These highlighted positions actually

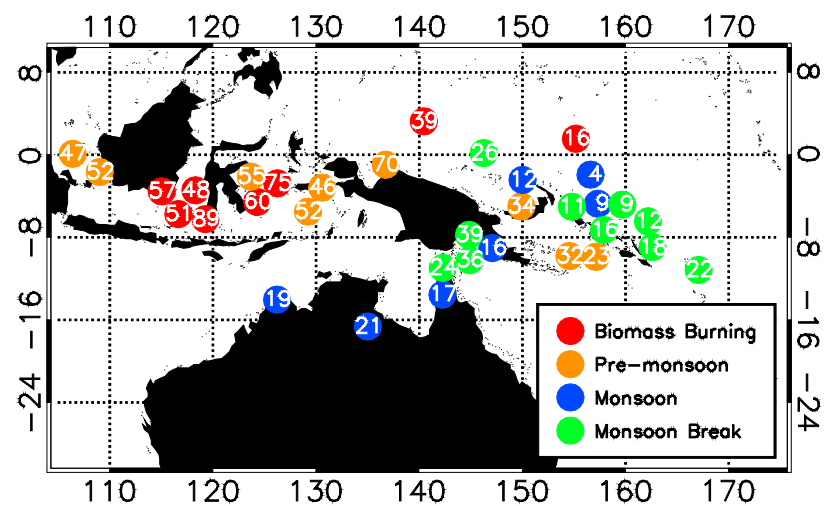

Fig. 5. Map showing the location where back trajectories that experienced rapid uplift crossed the $500 \mathrm{hPa}$ surface, colour-coded to meteorological phase. The values represent the concentration of ozone recorded by ozonesonde measurements at the beginning of the back-trajectory.

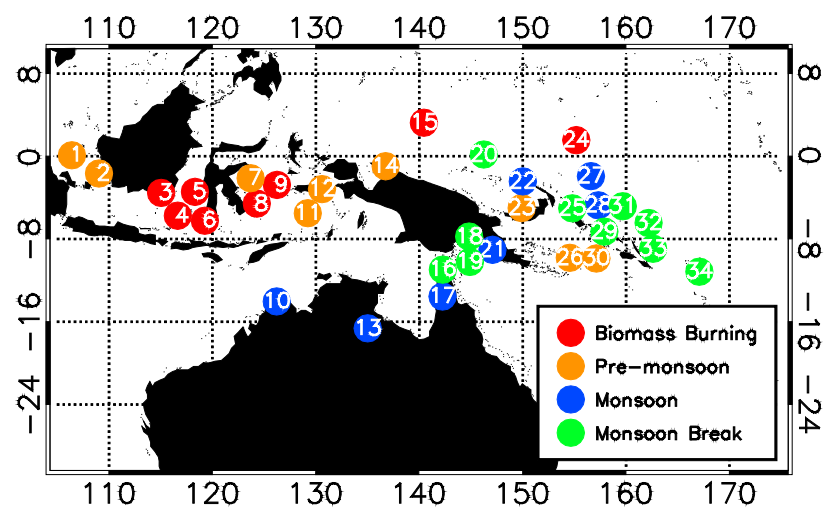

Fig. 6. As Fig. 5, where the trajectory positions have been numbered sequentially, to display the trajectory numbering used in Table 3.

represent a grouping of several trajectories within a given vertical ozone profile. The corresponding number of trajectories represented by each point is shown in Table 3. The number of days that each trajectory travels back before crossing the $500 \mathrm{hPa}$ surface is also shown in Table 3, rounded to the greater integer value, with the trajectory numbers corresponding to the locations in Fig. 6.

In general, across all meteorological phases, there is a distinct pattern in the ozone concentrations at the trajectory origins (Fig. 5). Trajectories uplifted over Indonesia, west of $140^{\circ} \mathrm{E}$, show high ozone concentrations, consistent with the MODIS satellite images (Fig. 1a), which show evidence of biomass burning, and hence ozone precursors, over Indonesia. In contrast, trajectories uplifted over the remote marine Pacific region show far lower ozone concentrations, consistent with the observations by Kley et al. (1996).

Differences in the origin of measured TTL ozone are also highlighted within phases of the same meteorological 
Table 2. The percentage of back-trajectories from the ozonesonde profiles uplifted past the $500 \mathrm{hPa}$ surface in the past ten days, grouped into pressure bins and meteorological phase, together with the aggregated average across the whole campaign.

\begin{tabular}{|c|c|c|c|c|}
\hline \multirow[t]{2}{*}{ Phase } & \multirow[t]{2}{*}{ Trajectory Levels $/ \mathrm{hPa}$} & \multicolumn{3}{|c|}{ Trajectories Uplifted/\% } \\
\hline & & & $\begin{array}{c}\text { Phase } \\
\text { Average }\end{array}$ & $\begin{array}{c}\text { Aggregated } \\
\text { Average }\end{array}$ \\
\hline \multirow[t]{4}{*}{ Biomass Burning } & $175-195$ & 83.3 & & \\
\hline & $150-170$ & 90.0 & & \\
\hline & $125-145$ & 73.3 & 67.5 & \\
\hline & $100-120$ & 23.3 & & \\
\hline \multirow[t]{5}{*}{ Pre-Monsoon } & $175-195$ & 30.0 & & \\
\hline & $150-170$ & 16.7 & & \\
\hline & $125-145$ & 13.3 & 17.9 & \\
\hline & $100-120$ & 11.7 & & \\
\hline & & & & 47.2 \\
\hline \multirow[t]{4}{*}{ Monsoon } & $175-195$ & 100.0 & & \\
\hline & $150-170$ & 73.3 & & \\
\hline & $125-145$ & 53.3 & 70.0 & \\
\hline & $100-120$ & 53.3 & & \\
\hline \multirow[t]{4}{*}{ Monsoon Break } & $175-195$ & 86.7 & & \\
\hline & $150-170$ & 100.0 & & \\
\hline & $125-145$ & 73.3 & 74.2 & \\
\hline & $100-120$ & 36.7 & & \\
\hline
\end{tabular}

regime. During the biomass burning phase (red circles) elevated and highly variable ozone concentrations arrive from Indonesia (48-89 ppbv; 4-7 days uplifted prior to arrival in Darwin), with low values of $\sim 16 \mathrm{ppbv}$ arriving from the western Pacific. This pattern continues for the few premonsoon trajectories which ascended (orange circles), where elevated and highly variable ozone concentrations originated over Indonesia (52-70 ppbv), whereas lower concentrations (circa $30 \mathrm{ppbv}$ ) arrived from the vicinity of the Solomon Islands.

Perhaps most surprisingly, during the monsoon phase when widespread convection was prominent around Darwin, long-range influences still dominated the local composition of the TTL. Monsoon trajectories uplifted over Northern Australia show consistent ozone concentrations of $\sim 20 \mathrm{ppbv}$, but the very low ozone concentrations ( $3-5 \mathrm{ppbv}$ ) of 22 January originate from the more distant Pacific region. Such concentrations are again consistent with the near-zero ozone concentrations recorded by Kley et al. (1996) over the Central Pacific. This pattern continues for the monsoon-break phase (green circles), when individual deep convective systems returned, with slightly elevated ozone concentrations ( 24-26 ppbv) close to Darwin and Indonesia, compared to the lower concentrations (9-12 ppbv) originating to the East.

In addition to the trajectories showing significant uplift into the TTL over Darwin, we show in Fig. 7 the full tenday back trajectory pathways, and in Fig. 8 the position reached after 10 days, for trajectories which did not experience uplift from below $500 \mathrm{hPa}$. These are colour-coded to meteorological phase, with Fig. 8 labelled with the associated ozone concentration from ozonesonde measurements, as before. Once again these are representative of groups of trajectories, with the corresponding number of trajectories in each group shown in Fig. 9.

Overall it is again observed that trajectories originating from the west possess higher ozone concentrations than those from the east and towards the Pacific Ocean. Trajectories arriving from Asia show intermediate values between these two extremes. The fact that these trajectories did not ascend significantly over their 10-day span does not prove that these air parcels were not ultimately affected by low-level sources, especially when considering the relatively long lifetime of ozone in the TTL and the ability for it (and its precursors) to be advected and mixed over large distances. As such this pattern simply acts to reinforce the picture of a dominant longrange influence on the TTL composition above Darwin.

\subsection{Trajectory analysis applied to carbon monoxide measurements}

In order to confirm the previous conclusions drawn from ozonesonde measurements, we now consider the carbon monoxide measurements from the Egrett. The Egrett aircraft flight patterns considered here were designed to sample convective anvils and background (clear) air. Evidence of perturbations to the $\mathrm{CO}$ concentration, consistent with uplift by convection, was seen during the anvil penetrations as patches of $\mathrm{CO}$ similar in concentration to measurements at lower 
Table 3. The number of aggregated trajectory clusters, and the number of integer days that each set of back trajectories travel back before crossing the $500 \mathrm{hPa}$ surface, for each trajectory position labelled in Fig. 6.

\begin{tabular}{|c|c|c|}
\hline $\begin{array}{l}\text { Trajectory } \\
\text { Position } \\
\text { in Fig. } 6\end{array}$ & $\begin{array}{l}\text { Number of } \\
\text { Trajectories } \\
\text { aggregated }\end{array}$ & $\begin{array}{c}\text { Time Taken for } \\
\text { Back Trajectories } \\
\text { to Cross } 500 \mathrm{hPa} \\
\text { Surface/Days (Integer) }\end{array}$ \\
\hline 1 & 6 & 9 \\
\hline 2 & 3 & 9 \\
\hline 3 & 7 & 4 \\
\hline 4 & 5 & 7 \\
\hline 5 & 7 & 4 \\
\hline 6 & 6 & 4 \\
\hline 7 & 10 & 10 \\
\hline 8 & 3 & 5 \\
\hline 9 & 4 & 6 \\
\hline 10 & 3 & 4 \\
\hline 11 & 12 & 10 \\
\hline 12 & 6 & 10 \\
\hline 13 & 5 & 2 \\
\hline 14 & 4 & 10 \\
\hline 15 & 10 & 4 \\
\hline 16 & 5 & 6 \\
\hline 17 & 10 & 5 \\
\hline 18 & 4 & 7 \\
\hline 19 & 9 & 5 \\
\hline 20 & 7 & 6 \\
\hline 21 & 3 & 4 \\
\hline 22 & 6 & 4 \\
\hline 23 & 2 & 7 \\
\hline 24 & 7 & 8 \\
\hline 25 & 10 & 6 \\
\hline 26 & 6 & 7 \\
\hline 27 & 7 & 3 \\
\hline 28 & 3 & 5 \\
\hline 29 & 3 & 5 \\
\hline 30 & 2 & 6 \\
\hline 31 & 5 & 5 \\
\hline 32 & 9 & 8 \\
\hline 33 & 2 & 9 \\
\hline 34 & 5 & 7 \\
\hline
\end{tabular}

altitudes; but, perhaps surprisingly, very little evidence for locally-uplifted air was found outside cloud, in background air. In this section we consider background, clear-air measurements of $\mathrm{CO}$ and analyse them through back-trajectories, in a similar manner to the ozonesonde profiles, in order to see whether these are consistent with the long-range influence inferred above.

For each straight and level transect the Egrett performed at altitudes higher than the $200 \mathrm{hPa}$ level, the in-cloud data was identified and removed using measurements from a SPEC cloud particle imager CPI-230 (sensitive to particles with

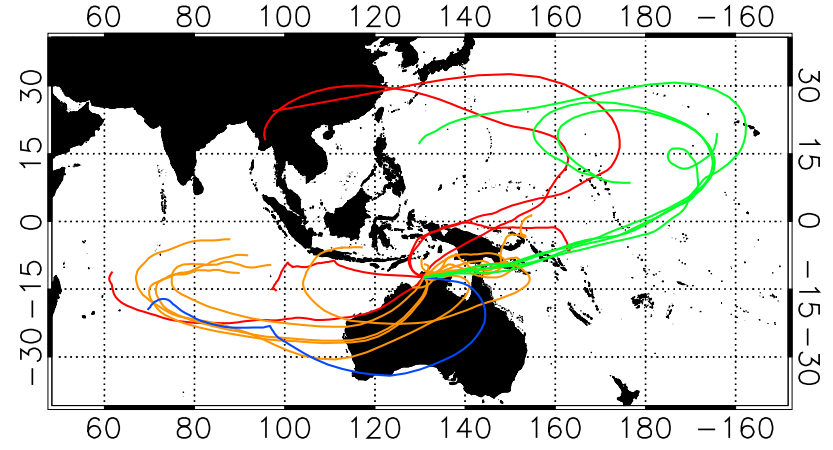

Fig. 7. Map analagous to Fig. 4 showing the full ten-day pathway for back trajectories which did not descend below $500 \mathrm{hPa}$, used in the analysis of ozonesonde data. Key as in Fig. 4.

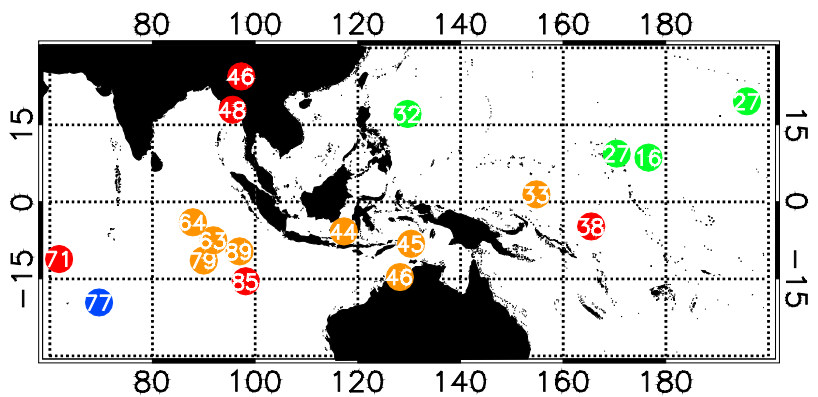

Fig. 8. Map showing the origin of 10-day back-trajectories which did not ascend from below $500 \mathrm{hPa}$, colour-coded to meteorological period, as in Fig. 5. The values represent the concentration of ozone recorded by ozonesonde measurements at the beginning of the backtrajectory.

diameters $30-2300 \mu \mathrm{m})$. The background $\mathrm{CO}$ measurement was noted not to vary greatly along the length of each transect, allowing for a mean out-of-cloud background $\mathrm{CO}$ concentration to be calculated. Back-trajectories were then performed from the aircraft position at 30-s intervals along the corresponding transect. The spacing of these trajectories meant that clusters were not required, as the consistency of a trajectory could be checked against its neighbours. Very few trajectories were rejected using the constraints discussed earlier. An example of the trajectories performed along a transect of the Egrett aircraft, and their general consistency, is shown in Fig. 10. As in the case of the trajectories initiated along the ozonesonde profile, a large number of these backtrajectories showed rapid, yet long-range ascent from low altitude. Table 4 indicates the percentage of trajectories that ascended through the $500 \mathrm{hPa}$ surface. The maximum operational altitude of the Egrett was only $15 \mathrm{~km}$, thus the percentage of uplifted trajectories closely resembles those for the ozonesonde profiles in the lower region of the TTL (Table 2). The percentage of uplifted trajectories is high $(>90 \%)$ for the biomass burning, monsoon, and monsoon break phases, but 


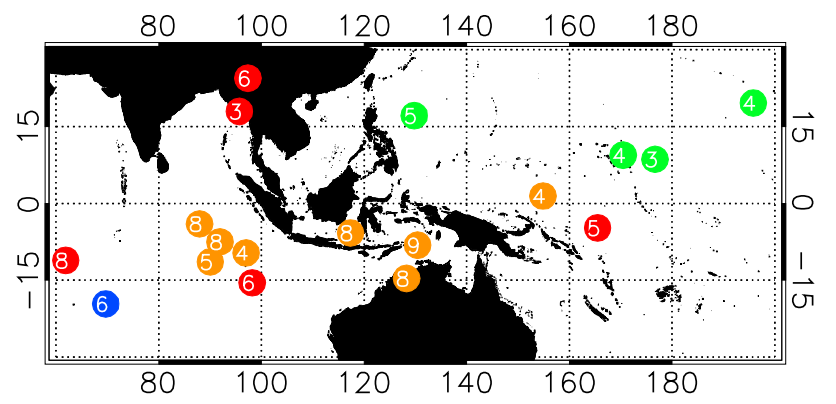

Fig. 9. As Fig. 8 where the values indicate the number of trajectories represented by the general origin location.

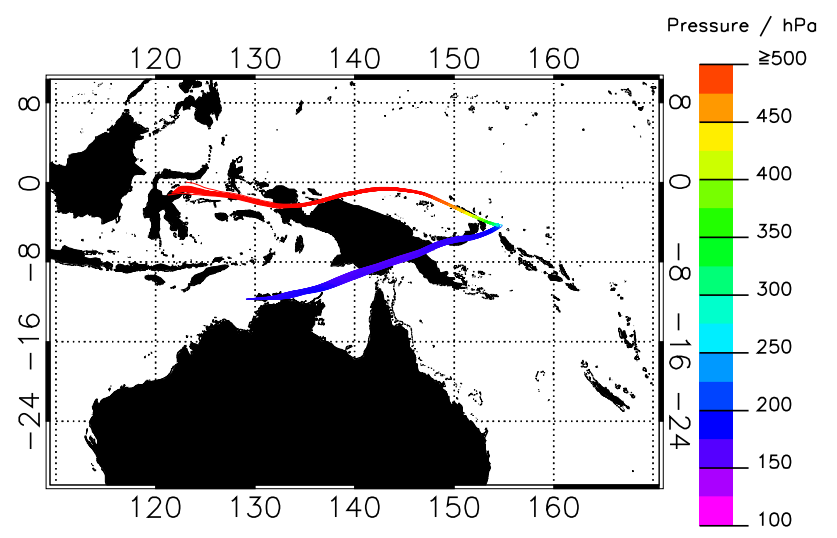

Fig. 10. An example of back-trajectories performed every 30 -s from Egrett aircraft location for the transect between 09:07-09:64 UTC for flight AE27 on 10 February 2006.

is much lower for the pre-monsoon phase, consistent with our earlier conclusion that long-range transport of previously uplifted air dominates the TTL composition over Darwin during this period.

Figure 11 shows the complete ten-day back trajectory pathways for those ascending from below the $500 \mathrm{hPa}$ level. Figure 12 shows the position that ascending trajectories crossed the $500 \mathrm{hPa}$ isosurface and their associated background (out-of-cloud) $\mathrm{CO}$ concentrations from aircraft measurements. The numbers of days along the trajectories to reach these positions are shown in Fig. 13. CO concentrations in the region 70-77 ppbv were uplifted over central Indonesia during the biomass burning period (red circles). The pre-monsoon period (orange circles) illustrates a contrast with trajectories uplifted over the east of Indonesia displaying more $\mathrm{CO}(78-81 \mathrm{ppbv})$ than those trajectories uplifted over the Pacific Ocean, where lower CO concentrations in the range 59-61 ppbv originated. The monsoon period (blue circles) showed general uplift in the Darwin region and slightly further north over Indonesia with highly consistent CO concentrations ranging from 51-56 ppbv. The monsoonbreak period (green circles) showed a clear gradient in carbon
Table 4. The percentage of back-trajectories initiated from Egrett transects uplifted past the $500 \mathrm{hPa}$ surface, sorted by meteorological period together with the overall total.

\begin{tabular}{lcc}
\hline Phase & \multicolumn{2}{c}{ Trajectories Uplifted/\% } \\
\cline { 2 - 3 } & Phase Average & Aggregated Average \\
\hline Biomass Burning & 90.5 & 71.8 \\
Pre-monsoon & 30.1 & \\
Monsoon & 98.4 & \\
Monsoon Break & 95.1 & \\
\hline
\end{tabular}

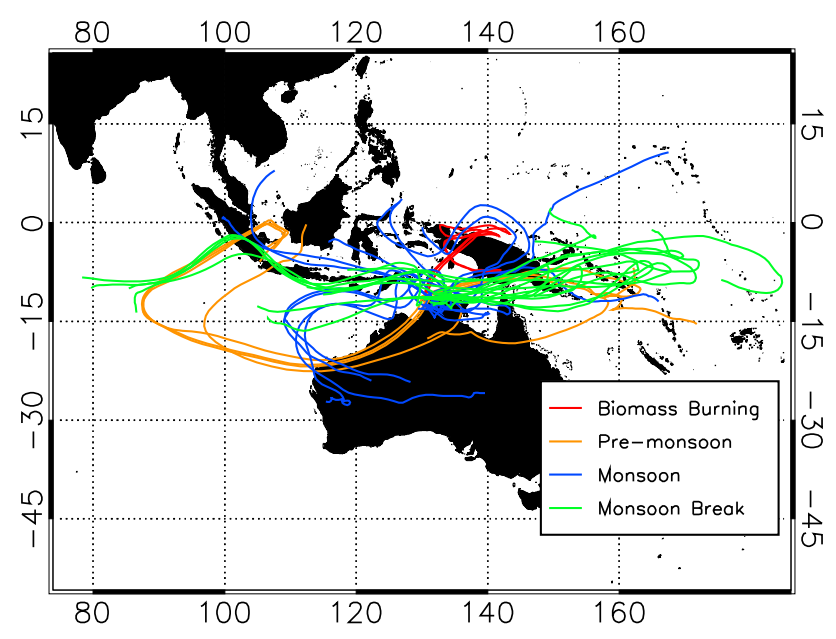

Fig. 11. Map analagous to Fig. 4 showing the full ten-day pathway for back trajectories uplifted from below the $500 \mathrm{hPa}$ surface, used in the analysis of carbon monoxide data.

monoxide dependent upon the position of uplift, consistent with our earlier discussion. Trajectories originating from the eastern edge of Indonesia showed elevated CO concentrations around 78-89 ppbv, whereas those showing significant uplift closer to Darwin and the maritime Pacific region showed reduced concentrations in the range 62-68 ppbv.

\subsection{The monsoon phase}

For the phases where individual deep convective systems dominated (i.e. biomass burning, pre-monsoon, and monsoon break) it is perhaps not surprising that transport via deep convection in the Darwin area does not significantly perturb the background TTL, since the convection is land-based and fairly localised. For the monsoon phase however Darwin experienced widespread deep convection, which could be expected to result in more effective vertical mixing. In this section we discuss results from the monsoon phase in greater detail.

In the monsoon period all the trajectories ending in the lower TTL over Darwin had ascended from low-levels 


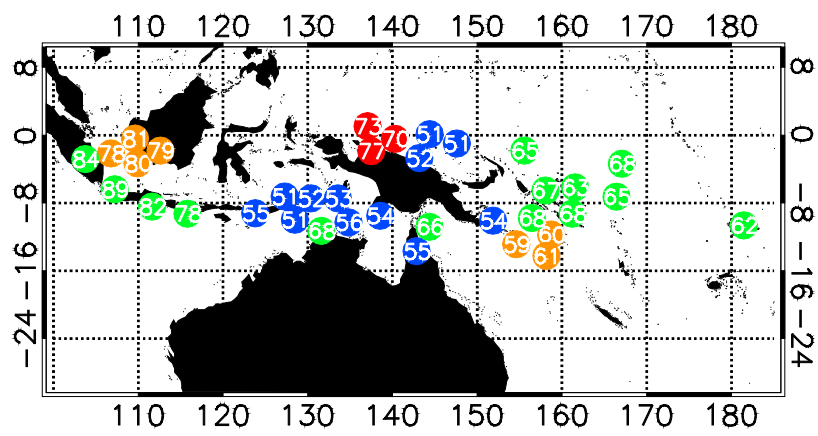

Fig. 12. Map showing the location where back trajectories that experienced rapid uplift crossed the $500 \mathrm{hPa}$ surface, colour-coded to meteorological period as in Fig. 5. The values represent the average background, out-of-cloud concentration of carbon monoxide recorded on the Egrett aircraft at the beginning of the backtrajectory.

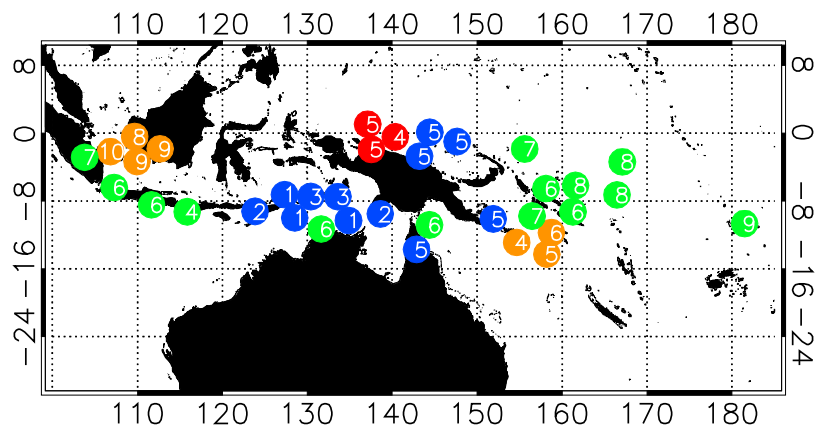

Fig. 13. As Fig. 12 where the values represent the integer number of days that the trajectories travelled before crossing the $500 \mathrm{hPa}$ surface.

(Table 2) with the associated ozone profiles showing a consistent 20 ppbv up to $14 \mathrm{~km}$ (Fig. 2). This suggests that local transport did determine the composition of the lower TTL during this period. This is supported by the Egrett CO measurements where, with the Egrett flying in the lower TTL and nearly all trajectories showing uplift from low-levels (Table 4), the $\mathrm{CO}$ values remained highly consistent and varied by only a few ppbv (Fig. 12). Thus, although the exact trajectory origins cannot be deduced in this regime, the general pattern of local uplift is confirmed by the aircraft CO. In the upper TTL, however, this is not the case. Variations in ozone concentration can be adequately accounted for only by uplift from the remote Pacific for low ozone concentrations (Fig. 5) or long-range advection where elevated ozone signatures are observed (Fig. 8) during this regime.

However, the aircraft ascent profile through the free troposphere on 20 January 2006 presents a cautionary note. Figure 14a shows the vertical profiles of both ozone and CO recorded by the Egrett on this day. As previously mentioned, the absolute ozone values from this instrument (a
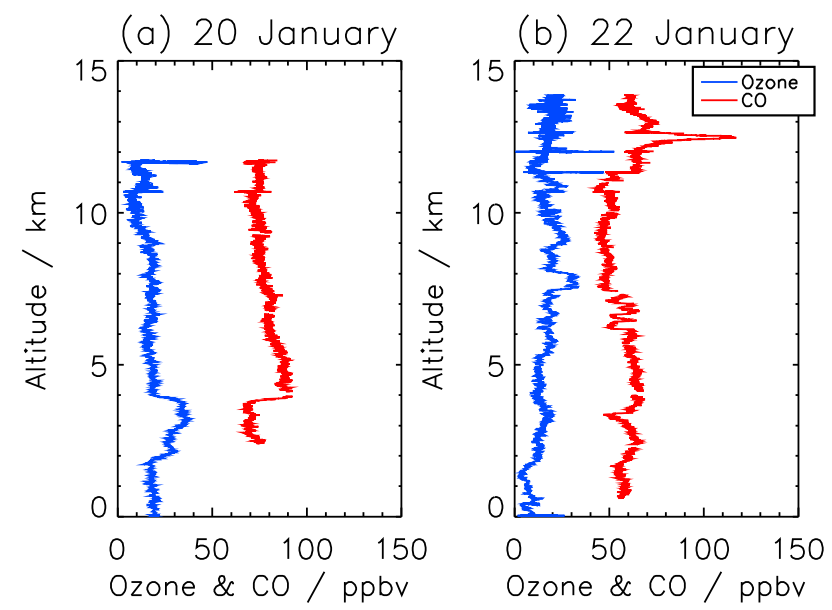

Fig. 14. Ozone and carbon monoxide vertical profiles recorded onboard the Egrett during the monsoon flight (a) AE17 on 20 January 2006 and (b) AE18 on 22 January 2006.

TECO 49 UV absorption instrument) are subject to uncertainty, but it was able to correctly depict qualitative changes in ozone. There is a clear step in both the $\mathrm{CO}$ and ozone profiles around $3.8 \mathrm{~km}$ (with an ozone increase coinciding with a decrease in $\mathrm{CO}$ ) which suggests the interleaving of air masses by horizontal advection, rather than rapid vertical mixing. The profiles from 22 January 2006 also show a similar structuring of layers throughout the free troposphere (Fig. 14b) suggesting that rapid convective mixing did not completely determine the composition of the lower troposphere during the monsoon. Note however that the lower TTL CO measurements showed little variation during this period, while the anvil (in-cloud) measurements varied between 65-74 ppbv, and 50-70 ppbv, on 20 January 2006 and 22 January 2006 respectively.

\section{Conclusions}

The origin of uplifted back-trajectories reaching the TTL above Darwin show a consistent and coherent pattern that accounts for the variations in both recorded ozone concentrations (from ozonesonde measurements) and carbon monoxide concentrations (from aircraft measurements). In general elevated ozone and carbon monoxide concentrations can be attributed to sources over the Indonesia area, with greatly reduced concentrations of both species showing a consistent origin from the tropical maritime Pacific region. The fact that these variations can be accounted for in this way suggests a long-range influence on the composition of TTL above Darwin. This is further supported by back-trajectories advected over the previous ten-days. Elevated ozone concentrations originated from a region to the far west of Darwin, with intermediate concentrations from low-altitude over Indonesia and Asia, and much lower concentrations from the remote 
Tropical Pacific. Hence, overall, the TTL above Darwin is governed by the composition of the wider Tropical Warm Pool area, as opposed to transport from the local boundary layer.

As expected, the convective influence varies with height (Fueglistaler et al., 2009). Results from the monsoon phase suggest that the lower TTL during this period is dominated by local transport from low-levels, with consistent ozone and $\mathrm{CO}$ concentrations coupled with near ubiquitous uplift, despite the cautionary note of the Egrett profiles which show that the lower troposphere was not completely mixed at this time. In the pre-monsoon, by contrast, even the lower TTL was affected mostly by long-range transport.

The fact that very low ozone concentrations were occasionally observed in the upper TTL above Darwin, which were tracked by the trajectory analysis to the Western Pacific, is strong evidence of widespread vertical mixing somewhere in this region: ozone is not destroyed photochemically in the (very dry) upper troposphere. This paper suggests therefore that the composition of the TTL is ultimately determined by vertical mixing in certain "hot spot" regions of the tropics, with advection from these regions dominating the composition elsewhere. Further research is required to confirm that similar measurements in such "hot-spots" would reveal a dominant influence from local uplift.

Although not a central element to their work, Brunner et al. (2009), performed a trajectory analysis for flights of the Geophysica aircraft as part of the SCOUT-O3 campaign (Vaughan et al., 2008), which was also conducted from Darwin between November and December 2005 (concurrent with the first period of the ACTIVE campaign). The authors concluded that air mass origin had a significant influence on measured concentrations of both carbon monoxide and ozone, supporting the conclusions drawn here.

Acknowledgements. We thank the pilots and ground crew of the Egrett and Dornier aircraft for ensuring a successful campaign, and to Peter May and the staff of the Bureau of Meteorology (BoM) Regional Centre in Darwin for their support in forecasting and logistics. We thank also the staff of the BoM radiosonde station, Darwin, for their support of the ozonesonde programme, Marcel Berg and Norbert Houben for maintenance of the CO instrument, and the Royal Australian Air Force for hosting the aircraft experiment. Finally, we thank the UK Natural Environment Research Council (Grant NE/C512688/1) and NERC Airborne Remote Sensing Facility for supporting ACTIVE. WH is a NERCsupported research student.

Edited by: D. Brunner

\section{References}

Allen, G., Vaughan, G., Bower, K. N., Williams, P. I., Crosier, J., Flynn, M., Connolly, P., Hamilton, J. F., Lee, J. D., Saxton, J. E., Watson, N. M., Gallagher, M., Coe, H., Allan, J., Choularton, T. W., and Lewis, A. C.: Aerosol and Trace-Gas Measurements in the Darwin Area during the Wet Season, J. Geophys. Res., 113, D06306, doi:10.1029/2007JD008706, 2008a.

Allen, G., Vaughan, G., Bower, K. N., Williams, P. I., Crosier, J., Flynn, M., Connolly, P., Hamilton, J. F., Lee, J. D., Saxton, J. E., Watson, N. M., Gallagher, M., Coe, H., Allan, J., Choularton, T. W., and Lewis, A. C.: Correction to "Aerosol and trace-gas measurements in the Darwin area during the wet season", J. Geophys. Res., 113, D23303, doi:10.1029/2008JD011284, 2008b.

Allen, G., Vaughan, G., Brunner, D., May, P. T., Heyes, W., Minnis, P., and Ayres, J. K.: Modulation of tropical convection by breaking Rossby waves, Q. J. Roy. Meteorol. Soc., 135, 125137, 2009.

Brunner, D., Siegmund, P., May, P. T., Chappel, L., Schiller, C., Müller, R., Peter, T., Fueglistaler, S., MacKenzie, A. R., Fix, A., Schlager, H., Allen, G., Fjaeraa, A. M., Streibel, M., and Harris, N. R. P.: The SCOUT-O3 Darwin Aircraft Campaign: rationale and meteorology, Atmos. Chem. Phys., 9, 93-117, 2009, http://www.atmos-chem-phys.net/9/93/2009/.

Crook, N. A.: Understanding Hector: The dynamics of island thunderstorms, Mon. Weather Rev., 129, 1550-1563, 2001.

Dickerson, R. R., Huffman, G. J., Luke, W. T., Nunnermacker, L. J., Pickering, K. E., Leslie, A. C. D., Lindsey, C. G., Slinn, W. G. N., Kelly, T. J., Daum, P. H., Delany, A. C., Greenberg, J. P., Zimmerman, P. R., Boatman, J. F., Ray, J. D., and Stedman, D. H.: Thunderstorms: An Important Mechanism in the Transport of Air Pollutants, Science, 235, 460-465, 1987.

European Centre for Medium-Range Weather Forecasts, ECMWF Trajectories, [Internet], British Atmospheric Data Centre, available from http://badc.nerc.ac.uk/data/ecmwf-trj/, last access: December 2006, 2006-2008.

Folkins, I., Loewenstein, M., Podolske, J., Oltmans, S. J., and Proffitt, M.: A Barrier to Vertical Mixing at $14 \mathrm{~km}$ in the Tropics: Evidence from Ozonesondes and Aircraft Measurements, J. Geophys. Res., 104(D18), 22095-22102, 1999.

Fueglistaler, S., Dessler, A. E., Dunkerton, T. J., Folkins, I., Fu, Q., and Mote, P. W.: The Tropical Tropopause Layer, Rev. Geophys., in press, 2009.

Gerbig, C., Schmitgen, S., Kley, D., Volz-Thomas, A., Dewey, K., and Haaks, D.: An improved fast-response vacuum-UV fluorescence CO instrument, J. Geophys. Res., 104 , 1699-1704, 1999.

Gettelman, A. and de Forster, P. M. F.: A Climatology of the Tropical Tropopause Layer, J. Meteorol. Soc. Japan, 80, 911-924, 2002.

Gettelman, A., de Forster, P. M. F., Fujiwara, M., Fu, Q., Vömel, H., Gohar, L. K., Johanson, C., and Ammerman, M.: Radiation balance of the tropical tropopause layer, J. Geophys. Res., 109, D07103, doi:10.1029/2003JD004190, 2004.

Highwood, E. J. and Hoskins, B. J.: The Tropical Tropopause, Q. J. Roy. Meteorol. Soc., 124, 1579-1604, 1998.

Holton, J. R. and Gettelman, A.: Horizontal Transport and the Dehydration of the Stratosphere, Geophys. Res. Lett., 28, 27992802, 2001.

Holton, J. R., Haynes, P. H., Douglass, A. R., Rood, R. B., and Pfister, L.: Stratosphere-Troposphere Exchange, Rev. Geophys., 
33, 403-439, 1995.

Kley, D., Crutzen, P. J., Smit, H. G. J., Vömel, H., Oltmans, S. J., Grassl, H., and Ramanathan, V.: Observations of Near-Zero Ozone Concentrations Over the Convective Pacific: Effects on Air Chemistry, Science, 274, 230-233, 1996.

Konopka, P., Gnther, G., Müller, R., dos Santos, F. H. S., Schiller, C., Ravegnani, F., Ulanovsky, A., Schlager, H., Volk, C. M., Viciani, S., Pan, L. L., McKenna, D.-S., and Riese, M.: Contribution of mixing to upward transport across the tropical tropopause layer (TTL), Atmos. Chem. Phys., 7, 3285-3308, 2007, http://www.atmos-chem-phys.net/7/3285/2007/.

May, P. T., Mather, J. H., Vaughan, G., Jakob, C., McFarquhar, G. M., Bower, K. N., and Mace, G. G.: The Tropical Warm Pool International Cloud Experiment (TWPICE), B. Am. Meteorol. Soc., 89, 632-645, 2008.

Pickering, K. E., Thompson, A. M., Scala, J. R., Tao, W., Dickerson, R. R., and Simpson, J.: Free tropospheric ozone production following entrainment of urban plumes into deep convection, J. Geophys. Res., 97, 17985-18000, 1992.

Reid, S. J., Vaughan, G., Marsh, A. R. W., and Smit, H. G. J.: Accuracy of ozonesonde measurements in the troposphere, J. Atmos. Chem., 25, 215-226, 1996.

Thompson, A. M., Tao, W.-K., Pickering, K. E., Scala, J. R., and Simpson, J.: Tropical Deep Convection and Ozone Formation, B. Am. Meteorol. Soc., 78, 1043-1054, 1997.
Thompson, A. M., Witte, J. C., McPeters, R. D., Oltmans, S. J., Schmidlin, F. J., Logan, J. A., Fujiwara, M., Kirchhoff, V. W. J. H., Posny, F., Coetzee, G. J. R., Hoegger, B., Kawakami, S., Ogawa, T., Johnson, B. J., Vomel, H., and Labow, G.: Southern Hemisphere Additional Ozonesondes (SHADOZ) 1998-2000 tropical ozone climatology - 1. Comparison with Total Ozone Mapping Spectrometer (TOMS) and ground-based measurements, J. Geophys. Res., 108(D8), 8238, doi:10.1029/2001JD000967, 2003.

Thuburn, J. and Craig, G. C.: On the Temperature Structure of the Tropical Substratosphere, J. Geophys. Res., 107(D2), 4017, doi:10.1029/2001JD000448, 2002.

Vaughan, G., Schiller, C., MacKenzie, A. R., Bower, K. N., Peter, T., Schlager, H., Harris, N. R. P., and May, P. T.: SCOUTO3/ACTIVE: High-altitude aircraft measurements around deep tropical convection, B. Am. Meteorol. Soc., 89, 647-662, 2008.

Volz, A. and Kley, D.: A Resonance Fluorescence Instrument for the In-Situ Measurement of Atmospheric Carbon Monoxide, J. Atmos. Chem., 2, 345-357, 1985.

Wilson, J. W., Carbone, R. E., and Tuttle, J. D.: Tropical Island Convection in the Absence of Significant Topography, Part II: Nowcasting Storm Evolution, Mon. Weather Rev., 129, 1637$1655,1999$. 